\title{
Nigeria: \\ Nomadic Migrancy and Rural Violence
}

\author{
Al Chukwuma OKOLI \\ Nsemba Edward LENSHIE
}

\begin{abstract}
Nomadism has been an age-long mode of pastoralism. Over the centuries, the practice has thrived amidst certain socio-ecological dialectics which has influenced its essence, including conflict and insecurity, climate change, urbanization, as well as changing patterns of land-use systems. Embedded in the practice of nomadism is the phenomenon of transhumant migration whereby pastoralists undertake a seasonally amenable geo-spatial sojourn in search of pasturable fields, resulting to both trans-local and trans-national migration. This pattern of migration has become a veritable source of security and livelihood threats in some parts of Africa in the contemporary times. This study explores the nexus between nomadic migrancy and rural violence in northern Nigeria against the backdrop of the degenerating complexion of nomadism in that context over the recent years. By means of a descriptive analysis, predicated on secondary sources and anchored on the 'ungoverned spaces' thesis, the study sets
\end{abstract} forth to establish how nomadic migrancy has accentuated and/or complicated the incidence of rural violence in the focal area. The study posits that non-regulation of nomadic migration and pastoralism by the Nigerian government has provided an opportunity for the perpetuation of violent crimes, such as rural banditry and herdsmen militancy in the focal area. The study makes a case for a pragmatic securitization of Nigeria's border and immigration governance systems as the way forward.

Keywords: Migration, migrancy, nomadic migrancy, Northern Nigeria, rural violence, ungoverned spaces.
Al Chukwuma OKOLI
Department of Political Science
Federal University Lafia, Nigeria
Email: okochu007@yahoo.com
Tel.: +234(0)8037849366

Nsemba Edward LENSHIE

Department of Political Science \&

International Relations

Taraba State University, Jalingo, Nigeria

Email: edward.lenshie@tsuniversity.edu.ng

Tel.: +234(0)7037067459

Conflict Studies Quarterly

Issue 25, October 2018, pp. 68-85

DOI:10.24193/csq.25.4

Published First Online: 05/10/2018 


\section{Introduction}

Nigeria is a country with huge governance deficits. It is a dysfunctional state, precariously slacking about holding effective sway over its territory and civil population. Governance deficits mean the inability of the government to effectively superintend its territories and frontiers in a manner that makes for sustainable national security. It presupposes the failure of the state in that context to perform the basic functions of governance, providing security, civil policing, education, healthcare, livelihood opportunities and law and order.

Nigeria's governance deficits also manifest in terms of the incapability of the Nigeria state to optimally harness and exploit its enormous human and natural endowments towards the goal of national development. Most fundamentally, governance deficits in Nigeria are saliently demonstrated by the country's frailty in upholding its territoriality and sovereignty in the face of internal or external existential threats. Important critical empirical indicators of governance deficits in Nigeria include endemic poverty, mass unemployment, prevalence of violence and criminality, terrorism, and the like. Challenges such as the aforementioned are not peculiar to Nigeria. Nonetheless, the apparent lethargy with which governmental authorities in the country have attended to the challenges smacks of functional irresponsibility.

The nonchalant posture of the Nigerian government towards governance has been most pronounced in the area of civil security. In this regard, the inability of the government to assume and exercise legitimate control or dominion over its territorial domain creates an avalanche of "ungoverned havens" that conduce for criminal impunity and intractability. This has been the case with the contemporary challenge of nomadic migrancy, which has been associated with high incidence of rural violence in northern Nigeria. In this context, the salient analytical posers of the study include understanding the nature of contemporary nomadic migration in northern Nigeria, how nomadic migrancy correlate with the rising incidence of rural violence in northern Nigeria, and the implications nomadic migrancy has for national security in Nigeria.

Situating its arguments within the analytical prism of the 'ungoverned spaces' thesis, the study posits that the non-regulation of nomadic migration and pastoralism by the Nigerian government has complicated the incidence of rural violence in northern Nigeria by accentuating the prevalence of rural banditry, herdsmen militancy and arms proliferations in that context. Arising from the analytical premise of a threat-import analysis, the study submits that nomadic migrancy holds critical implications for national security in Nigeria. This article is systematically structured into seven sections to properly engage the discourse. The first section introduces the discourse by situating hypothetically the nexus between nomadic migrancy and rural violence, associating the pathology with the prevalence of governance deficits in Nigeria. The second section clarifies and contextualizes nomadic migrancy, rural violence and nomadism as the 
conceptual thrusts of the study. The third section presents the ungoverned spaces thesis as an analytical framework of the study. The fourth section provides some reflective perspectives on pastoral migration in an attempt to explore the extant literature on the subject matter. The fifth section concentrates on the complex interplay of nomadic migrancy, ungoverned spaces, and rural violence in northern Nigeria. The sixth section examines the implications of the nomadic migrancy challenge for national security in Nigeria. The last section concludes by making salient submissions with policy implications and recommendations.

\section{Conceptualizing and Contextualizing Basic Variables}

Three key variables constitute the conceptual thrust of the present discourse, namely rural violence, nomadism and nomadic migrancy. The sub-sections that follow present the operational meanings of the variables alongside a number of contextual nuances designed to properly situate their understanding.

2.1 Nomadic migracy: This refers to a pattern of migration and settlement associated with pastoral nomadism. It presupposes the movement and/or sojourn of nomadic herdsmen from one location to another in pursuit of ecological survival, economic substance and sustainable livelihood. The movement can be translocal or transnational, depending on its origination-to-destination equation vis-à-vis national boundaries. Nomadic migrancy in Nigeria is characterized by sporadic influx of herdsmen into the country, especially from the Niger-Chad corridor of the country's northern borderlines. Over the years, this phenomenon has exploited the faultiness border porosity in the country towards constituting a national security threat.

2.2 Rural violence: By violence it meant "the intentional use of force or power, threatened or actual, against oneself, another person, or against a group or community that either results in or has the likelihood of resulting in injury, death, psychological harm, mal-development or deprivation" (Krung, Dahlberg, Mercy, Zwi \& Locano, 2002, p. 6). Rural violence, therefore, refers to a situation whereby a person, group or community in the hinterlands (countryside) is deliberately inflicted with death, injury, or any form of psycho-social harm. Rural violence thrives in the context of socio-political and agrarian contestations (Kay, 2001). It is also associated with armed criminality (Ceccato \& Ceccato, 2017), especially in the context of fragile state.

Drivers of rural violence in Nigeria include communal disputations pertaining to identity politics, power sharing, resource control, chieftaincy tussles, etcetera. This is in addition to various dimensions of armed criminality, such as banditry, cattle rustling, kidnapping, cultism and youth-related brigandage (Okoli \& Okpaleke, 2014). There has been a rising trend of rural violence in Nigeria over the years. This development has been exacerbated by the incidences of arms proliferations and organized militancy 
in the countryside, amidst the "government's fecklessness in dealing with the threat" (Federal Research Division-Library of Congress, 2008, p. 137).

2.3 Nomadism: Our understanding of nomadism in this context presupposes pastoral nomadism. It refers to a subsistence practice or strategy that is based on itinerant subsistence whereby a pastoral group or community moves from place to place in prospect of a "pastorable" livelihood. Pastoral nomadism is basically a pattern food producing economy as distinguished from other forms of food extracting economy such as hunting and gathering, fishing (Khazanov, 1994). More precisely, pastoral nomadism has been conceptualized "... as distinct form of food-producing economy in which extensive mobile pastoralism is the predominant activity, and in which the majority of the population is drawn into periodic pastoral migrations" (Khazanov, 1994, p. 17).

Pastoral nomadism is a 'socio-ecological mode' of culture that has coexisted as an alternative to agricultural sedentism and urban living (Scholz, 1995). Beyond being an agrarian practice, nomadism typifies a cultural system with salient socio-ecological essences and dynamics. These include temporally and spatially ubiquitous settlement, mobile pastoralism and transhumance political economy (Egwu, 2016). Nomadism in West Africa is associated traditionally with the Fulani. In Nigeria, the practice has been inhibited by the adversities of climate change, civil conflicts, urbanization, population explosion, and insecurity. Over the recent years, the practice has become rather estranged and precarious, apparently degenerating into the morass of rural banditry and armed militancy.

\section{Theoretical Framework: The Ungoverned Spaces Thesis}

In interrogating nomadic migrancy and rural violence in northern Nigeria, the ungoverned spaces thesis has been adopted. The choice of ungoverned spaces thesis is motivated by the fact that previous studies on the complex nature, dynamics and consequences of nomadic migrancy were predicated on eco-violence (Homer-Dixton, 1994, 1999; Okoli \& Atelhe, 2014; Odoh \& Chigozie, 2012; Awogbade, Olaniyan, \& Faleye, 2016), competitive control of resources (Fisher \& Mercado, 2014), competing governance (Forest, 2010), intractable conflicts (Northrup, 1989; Coleman, 2000; Putnam \& Wondolleck, 2003; Gray, Coleman, \& Putnam, 2007; Smith, 2014), modernization triggered by cultural change and democracy (Newman, 1991; Inglehart \& Welzel, 2005) and the Marxist political economy (Marx and Engel, 1968; Ensminger \& Rutten, 1991) approaches.

As plausible as these analytical frameworks are in explaining phenomenon of the type investigated, they tended to have given less consideration to the role of the state and the place of governance in the crisis associated with the nomadic migrancy responsible for rural violence. From this context, the ungoverned spaces thesis is found to have the capacity of explaining the salient dialectics of criminal and subversive activities within 
Nigeria's ungoverned spaces, which have posed serious threats to the existence of the nation.

The ungoverned spaces thesis fertilized in the post-9/11 era featured remarkably in a report developed by the American think-tanks with the RAND Corporation (Rabasa, Boraz, Chalk, Cragin, Karasik, Moroney, O’Brien, \& Peters, 2007). The concept of ungoverned spaces was popularized by Hillary Clinton, the former Secretary of State in the United States of America, when she addressed the Afghanistan-Pakistan border as ungoverned spaces (Marsden, 2017). Since then, publicists, scholars, researchers and policy-makers have used ungoverned spaces thesis to investigate and engage discourses involving different strands of domestic and global security concerns.

Contemporary security concerns, particularly in sub-Saharan Africa, have tended to lend credence to the ungoverned spaces thesis, to the effect that sovereign void exemplified in governance deficit exist in Africa. As Keister (2014) puts it, ungoverned spaces reflect a general condition of weak or non-existence of state authority in a defined geographic area. In other words, ungoverned spaces relate to areas where there are governance deficits or absence of control over areas of specific or general concerns. Without effective state's control, or under the atmosphere of ungoverned spaces, also referred as "anarchic zones", state's security becomes precarious (Fall, 2015; Taylor, 2016; Coleman, 2000).

The ungoverned spaces thesis presents definitively exploitable and contested spaces that often come under the illegitimate control of gangs, local armed groups, militants and/or warlords as a result of under-governance, misgovernance or the total absence of governance within a definable space (Raleigh \& Dowd, 2013; Whelan, 2005, 2006; Lamb, 2008; Clunan \& Trinkunas, 2010). In this context, a shadow state or authority emerges to contest the authority of the state (Taylor, 2016; Mallet, 2010; Whelan, 2006), through local networks within and across the state.

The problems of ungoverned spaces are contingent on certain conditions, including the size of the state, population growth, density and spatial distribution, as well as the pattern of wealth distribution. Other conditions may include urbanization, globalization and increase wealth of non-state actors and lack of capacity to exercise effective control of territorial boundaries, as well as the government complacency toward the security threats (Menkhaus, 2007; Keister, 2014; Julum \& Evans, 2015).

It is the sole responsibility of state to provide and guarantee national stability through security governance. The purpose of security governance is to mitigate conditions that have the tendencies of leading to the problems such as that of ungoverned spaces. Security governance in this context implies the exercise of effective governance through social provision of human security as well as national security. The essence of security governance is to guarantee the safety of lives, property, livelihoods, and territoriality in state through the monopoly of legal violence (Lenshie, 2018; Coleman, 2000). 
The ungoverned spaces thesis has been criticized for excessively being Western in analyzing security issues, in that the thesis is framed against non-Western states viewed as constituting security threats to the Western countries as a result of their weaknesses (Menkhaus, 2010; Feldman, 2009; Andrew, 1975). Some of the reasons explicated for such analysis stem from the fragility of states in developing countries, particularly in the Middle-East and Africa. Poor governance, porous state's boundaries and weak security institutions are some of the conditions attributed for the prevalence of ungoverned spaces in these continents (Raleigh, 2013; Martin, 2003).

Western scholars and publicist believe that chaos in these parts of the world have deleterious effects on the Western world (Diggins, 2011; Andrew, 1975; Feldman, 2009). The scenario implies that ungoverned spaces are generally manifest in dysfunctional states. Nonetheless, even the strong states also suffer the consequences of ungoverned spaces that are internal to them (Lenshie, 2018; Marsden, 2017).

Despite the criticism of the ungoverned spaces thesis, it has been found to be plausible in analyzing the intersection between nomadic migrancy and rural violence in Nigeria. The thesis implicates the government of Nigeria for permitting the emergence of contested, ungoverned, misgoverned and exploitable spaces controlled by networks of criminalities under different identities. One of such spaces is the unregulated practice of nomadic migrancy, which has yielded violence in many parts of rural northern Nigeria. In the recent time, Nigeria has witnessed unprecedented nomadic migration from other countries. These nomads are undocumented and unregulated. The porous nature of the Nigeria's boundaries makes it possible for the influx of nomadic migrants in the country.

The consequences of uncoordinated governance are incidences of rural banditry, herdsmen militancy and arms proliferations, which instantiate rural violence in most parts of the northern Nigeria. The failure of the government of Nigeria to exercise effective sovereignty or control of the ungoverned spaces within its territorial confines and frontiers, explains the criminal dynamics in the ungoverned spheres (Olaniyan \& Akinyele, 2017; Ali, 2017).

\section{Perspectives on Pastoral Nomadism/Nomadic Migration}

Pastoral nomadism is a cultural cum occupational practice whereby herds are maintained all year round based on a system of free-range, extensive grazing (Goodall, 2007). It is essentially a mobile form of food-producing economy, entailing the periodic movement of a substantial percent of the population of a pastoral community in accordance with the dialectics of pastoral economy (Khazanov, 1994). According to Khazanov (1994) the most salient characteristics of pastoral nomadism are:

(1) Pastoralism is a predominant form of economic activity (2) Its extensive character connected with the maintenance of herds all year round on a system 
of free-range grazing without stables (3) Periodic mobility in accordance with the demands of pastoral economy within the boundaries of specific grazing territories, or between these territories (as opposed to migrations) (4) The participation in pastoral mobility of all or the majority of the population (as opposed, for example, to the management of herds on distant pastures by specialist herdsmen, into which only a minority is involved in pastoral migrations

(5) The orientation of production towards the requirement of subsistence (as opposed to the capitalist ranch or dairy farming of today (p. 160).

From the foregoing, whether it is the majority or minority of the population that is involved, pastoral nomadism entails necessarily a level of communal migration. This movement involves the herders alongside their herds, often in company of members of the herding clan. Therefore, nomadic migration is, above all, motivated by economic rationalism. As Kurekova (2011) stated, it is "stimulated primarily by rational economic consideration of relative benefits and costs" (p. 4).

Depending on the seasonal variability as well as other salient socio-structural interveners within a pastoral ecology, nomadic migration usually tends from areas of high pastoral costs towards areas of high pastoral benefits. 'Pastoral costs' refer to the prevalence of occurrences that undermine effective and rewarding pastoralism, such as drought, desertification, civil strife, disease, insurgency, and so on. 'Pastoral benefits', on the other hand, have to with the availability pasture and fresh water, as well as assurance of peace and security (Egwu, 2016).

Nomadic migration is a veritable livelihood strategy open to all nomadic communities (McDowell \& Haan, 1997). It enables the herders navigate through social and ecological hazards that often confront their occupation in an effort to ensure survival and sustainability of livelihood. In addition to the imperative of survival, migration also helps nomadic communities to access new rangelands, locate new markets for their produce, and establish new transhumant linkages and ties (Mulianga, 2009).

Adriansen (2005) observes that nomadic migration "is highly appropriate in a variable and unpredictable environment" (p. 208). According to him:

Pastoral mobility implies that pastoralists can move to areas with pasture for their livestock. Moreover, pastoral mobility means that the effect of unforeseen events, e.g. outbreak of disease, bush fire, locust attack, can be mitigated. Finally, migration between different agro-ecological zones means that more animals can be kept than in each of the zones (p. 208).

In other words, nomadic migration guarantees a high pastoral productivity, resilience and sustainability. With that, the subsistence of the pastoral community is guaranteed on a sustainable basis. 
Broadly, two patterns of nomadic migration are identifiable, namely routine seasonal migration and 'emergency' migration (Janzen, 2005). The former is dictated by the exigencies of seasonal variability while the latter is often informed by the need to escape climatic, civil, or health-related adversities such as drought, pestilence, conflict, etc. Whatever be the reason, nomadic migration has its essence in a "spatio-temporal movement" in search of a favourable rangeland (Mulianga, 2009, p. 1).

Nomadic migration can be translocal or transnational (Lee, 2009). Translocal migration occurs within the territories of a country while transnational migration occurs across the borders of countries. The crossing of international boundaries by herdsmen in Africa typifies the reality of irregular migration (International Organization for Migration [IOM], 2011). According to the IOM (2011), irregular migration is "movement that takes place outside the regulatory norms of the sending, transit and receiving countries" (p. 54).

Nomadic migration to and fro the borderlines of Nigeria are largely unregulated. This has created an illicit economy around the nomadic business giving rise to organized crimes such as smuggling, trafficking in humans and drugs, and cattle rustling (IOM, 2011). It has also provided avenues for terrorism and/or insurgency financing (Okoli, 2017). The abusive instrumentalization of nomadic migration by organized criminals and insurgents/ terrorists has raised a pertinent national security concern in Nigeria. The sections that follow will engage this important concern.

\section{Nomadic Migrancy, Ungoverned Spaces, and Rural Violence in Northern Nigeria}

Nigeria is a territorially challenged and fragile state. It is characterized by what we may term "virtual territorial ungovernability". This existential syndrome is evident in the near absence of governmental presence and control within critical domains of the country's wider territorial sphere. Nigeria's territorial ungovernability is thus instantiated by the huge governance deficits in the country's physical and maritime boundaries, cyberspace, forest areas, as well as mainland, airways and waterways.

Nigeria's ungoverned spaces syndrome is most saliently and vividly demonstrated by the vast and porous borderlines of the country. The Nigeria World Today (2017) is of the view that "Nigeria borders are vast with hundreds of footpath, overlapping to the adjoining countries of Chad, Cameroon and Niger, with links to Sudan, Mali and Libya" (para. 5). The source adds that:

... there are more than 250 walkways from Maiduguri, Damaturu axis to Niger, Chad or Cameroon. Most of these paths are unknown to the security agencies and are neither manned nor guarded and they are being used frequently by criminals to sneak in (sic) instrument of death into the country (para. 5). 
In addition to its woefully porous boundaries and borderlands, Nigeria's countryside is equally characterized by acute ungovernability. There are vast expanses of rangelands and forests that are physically and functionally separated from the sphere of effective state control. These ungoverned spaces have often been occupied and utilized by criminals, insurgents and terrorists as operational strangleholds (Okoli \& Ochim, 2016).

How does the foregoing apply to the phenomenon of nomadic migrancy? First, nomadic migrancy is a phenomenon that festers within the typically ungoverned spaces of the Nigerian territory, namely the porous boundaries and borderlands, the scarcely governed rangelands and forestlands, and the poorly policed hinterlands in the countryside. Secondly, nomadic migrancy itself is an activity that is hardly regulated by the law. Obtaining largely outside the formal regulatory regime of the state, the practice is bound to be abused. This is evident in the bastardization of the practice by criminals, insurgents and terrorists who capitalize on the governance deficits in the sector to perpetrate felonious acts. The sub-sections hereunder attempt to put the foregoing argument into empirical perspective, drawing from selected evidences from northern Nigeria.

Suffice it to state that the ungoverned nature of nomadic migration in Nigeria has created an enabling environment for criminal impunity in the sector. This has led to critical outcomes that complicate and accentuate the incidence of rural violence in northern Nigeria, with dire implications for nation security of the country.

5.1 Nomadic migrancy and arms proliferations: Nomadic herdsmen have been involved in arms proliferations in two important ways. First, they bear arms, ranging from rudimentary to modern weaponry. Nowadays, it is common to see Fulani cowboys brazenly armed with sophisticated weapons, such as AK-47, in the course of their routine grazing. The weapons are ostensibly borne for self-defense, and possibly, to ward off traditional threats of cattle rustling and banditry (Egwu, 2016). Unfortunately, it is the same weapons that the herdsmen use in raiding settled communities at every instance of a major confrontation (Bonga, 2017).

Besides the issue of arms bearing, the herdsmen have also been implicated in arms smuggling and running (trafficking). According to Nigeria World Today (2017):

It is unfortunate that the Fulani Herdsmen have devised mean (sic) of smuggling arms into Nigeria through the footways. The methods they employ include the use of their cattle. The fact that the weapons are light and collapsible makes it easy to be hidden and transported with cattle. The ammunition are (sic) attached to the bellies of the cows with specially crafted skin bags majoring meant for illegal mission undetected (para. 6).

Reinforcing the claims of the above citation, Omitola (2014, slide 14) opines' that "Fulani herdsmen have been reported to be involved in transporting (of) small arms to Nigeria through their cattle". The smuggling and trafficking of arms, as well as the 
blatant use of same, by the herdsmen has complicated the challenge of arms proliferations in northern Nigeria.

5.2 Nomadic migrancy and rural banditry: Nomadic migration has contributed to the escalation of rural banditry in northern Nigeria. This is evident in the spate of armed robbery, cattle rustling and kidnapping wherein herdsmen have been implicated. Crops of herdsmen displaced by conflict and climatic adversities in the Sahel have migrated to parts of northern Nigeria where they have taken to guerilla criminality. In places like Borno, Yobe, Bauchi, Adamawa, Gombe and Jigawa States, they have often operated as high-way robbers (locally referred to as Kwanta-Kwanta), molesting passers-by on the inter-state roads (Okoli \& Okpaleke, 2014).

In Zamfara-Kebbi axis of North West Nigeria, rural banditry has assumed a sophisticated dimension with the emergence of forest-based nomadic bandits who specialize in cattle rustling, kidnapping as well as market and village raids (see table 1 below). In Zamfara State, the criminals have effectively occupied the major neighbouring forests from where they launch incessant attacks on hapless communities in the hinterlands of the State.

Table 1: Estimated Number of Livestock Rustled in the Zamfara State in 2016

\begin{tabular}{clr}
\hline S/No & \multicolumn{1}{c}{ Area } & Number of Livestock \\
\hline 1 & Badarawa & Over 200 \\
2 & Bagega & Over 4,500 \\
3 & Dorayi & Over 2,500 \\
4 & Filinga & Over 5,000 \\
5 & Gidan Kaso & 1,455 \\
6 & Guru & 270 \\
7 & Jangeme & Over 600 \\
8 & Kizara & Over 4,000 \\
9 & Lilo & 90 \\
10 & Lingyado & Over 2,100 \\
11 & Madaba & 106 \\
12 & Nasarawa Godal & Over 1,000 \\
13 & Nasarawa Mai Layi & Over 500 \\
14 & Rukudawa & 250 \\
15 & Shigama and Kwokeya & 1,020 \\
16 & Tsabre & Over 3,500 \\
17 & Tungar Baushe & 1,110 \\
18 & Unguwar Galadima & 850 \\
19 & Yar gada & 230 \\
\hline
\end{tabular}

Source: MACBAN (2016) as cited in Rufai (2016, p.6).

In North Central Nigeria, rural banditry orchestrated by the migrant herdsmen and their local cohorts has led to a convolution of rural criminality and violence. While some have engaged in cattle rustling, others have taken to kidnapping and robbery. A recent arrest by the Nigerian police of a gang of kidnappers who doubled as herdsmen 
in Niger State is instructive. Regarding this incident, Uwujire (2017) reports:

In addition to kidnapping, they engaged in robbery, dispossessing the hapless victims of both cash and valuables. After the operations, they would simply disappear into the bush and resume tending to their cattle, an activity that provided perfect cover for the criminal acts (para. 4).

Elsewhere, in North Central Nigeria, incidents of rural banditry involving the herdsmen have been pervasive. States, such as Benue, Nasarawa Plateau, have become critical hotbeds of cattle rusting (see table 2 below). Cattle rustling are a specialized criminality that requires some nomadic prowess. Driving a herd of rustled cattle along the hazardous bush paths for days and nights certainly requires an expertise that only an experienced nomadic cowboy can offer. In effect, it takes the involvement of an experienced herdsman to effectuate cattle rustling in any case (Okoli, 2016). This highlights the culpability of the migrant herdsman to the act.

Table 2: Estimated Incidence of Cattle Rustling in Central Nigeria (2013 to early 2015)

\begin{tabular}{lcc}
\hline \multicolumn{1}{c}{ State } & No. of Cattle Rustled & No. of Human Casualty \\
\hline Plateau & 28,000 & 264 \\
Nasarawa & 25,000 & 70 \\
Benue & 8,680 & 2,500 \\
Kwara & 1,640 & 150 \\
FCT & 1,500 & 7 \\
Total & 64,820 & 2,991 \\
\hline
\end{tabular}

Source: Weekly Trust (2015, May 16), as cited in Okoli (2016, p. 418).

Fulani herdsmen have also been involved in nightly and highway robberies in Central Nigeria. In Nasarawa State, for instance, they have been responsible for most of the market-day road-robberies in the hinterlands. They have equally been involved in nightly robbery attacks in the urban centers and suburbs of the State (Okoli, 2016). The scenario is more or less the same in parts of the neighboring States of Kaduna and Taraba, where the contours of rural banditry have been life-threatening.

5.3 Nomadic migrancy and herdsmen militancy: The dominant herding community in Nigeria is the Fulani. The Fulani are traditionally a nomadic tribe with immense sense of group solidarity. The cult-like solidarity manifests powerfully in their relationship with out-groups. When faced with a threat emanating from the out groups, the Fulani are inclined to mobilize supports from their national and transnational tribal networks, even in terms of military logistics and resourcing. This tendency has played out in the context of the perennial farmer-herder conflicts in Nigeria, whereby fighters are recruited by the herdsmen from their clans in the Diaspora to fight for them. Most of the perpetrators of herdsmen militancy arrested in various places in North Central Nigeria have incidentally been found to be foreign Fulani. 
The organized militias fighting on the side of the Fulani in most instances of farmerherder crises in Northern Nigeria have been found to consist largely of Fulani from the Sahel and Magrib (Nigeria World Today, 2017, para. 8). The involvement of these elements in the crises has not only complicated matters, it has resulted in huge humanitarian crises that negate sustainable human security in Northern Nigeria and beyond.

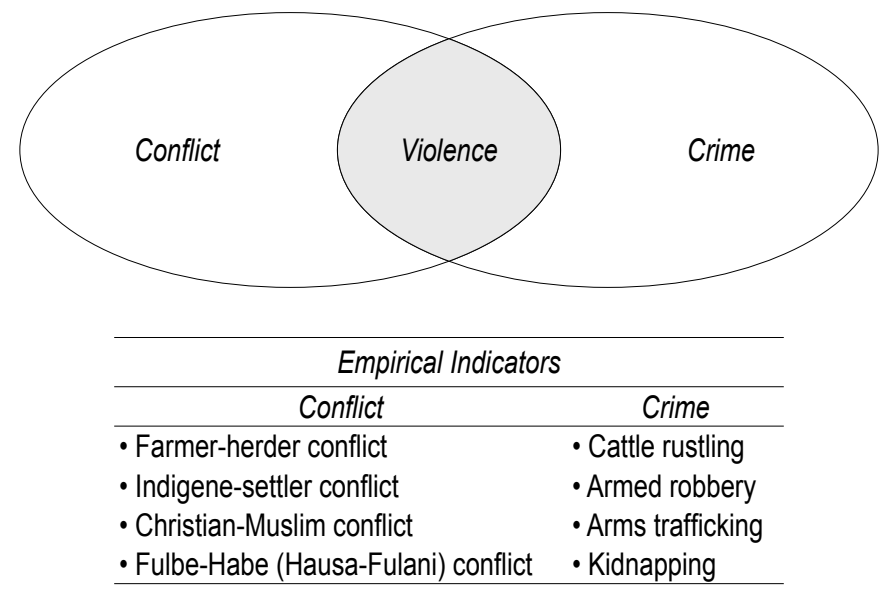

Figure 2: The Conflict-Crime Nexus of Nomadic Migrancy

Source: Authors' concept, 2018.

Nomadic migrancy has been associated with the vicious outcomes of conflict and crime whose indicators are highlighted in figure 2 . The critical outcomes intersect on violence, with requisite crisis and instability manifested in the forms of farmer-herder conflict, indigene-settler conflict, Christian-Muslim conflict and Fulbe-Habe conflict, as well as cattle rustling, armed robbery, arms trafficking and kidnapping in northern Nigeria. The implications involving the various dynamics of conflicts and criminalities are great and deleterious for national security in Nigeria.

\section{Nomadic Migrancy: Implications for National Security}

Nomadic migrancy constitutes a threat to national security in Nigeria. It has provided an avenue for irregular and undocumented influx of migrant herdsmen into the country. Locally, it has resulted in unrestrained and often provocative movement of herdsmen from one part of the country to another. The unregulated nature of these movements means that it could be capitalized upon by criminal or terrorist elements towards undermining the security of the nation. This has, indeed, been the situation.

As we have established in the course of our analysis in this study, the ungoverned terrain of nomadic migrancy in Nigeria has provided ample opportunities for the perpetration of organized crime by local and transnational syndicates operating as or in the guise of 
herdsmen. The proven complicity of migrant herdsmen involving in arms trafficking, cattle rustling and kidnapping in northern Nigeria, point to the ominous fact that an underworld economy of violence cum criminality is festering alongside unregulated nomadic migration.

More ominous is the fact that migrant herdsmen have been implicated in the on-going insurgency and militancy in the North-Eastern and North-Central Regions respectively (McGregor, 2014; Olayoku, 2014). Apart from rustling cows and trafficking arms for Boko Haram insurgents, migrant herdsmen have orchestrated lethal violence in parts of North Central Nigeria. The orgy of violence in North Central Nigeria has been very pervasive and prevalent over the recent years. The trajectory of the violence points to the arrival of another genre of insurgency in the country in addition to the Boko Haram menace.

Equally disturbing is the involvement of migrant herdsmen in communal conflicts in northern Nigeria. This trend is evident is the ethno-communal/religious conflagrations in States such as Kaduna, Taraba, Zamfara, and the bulk of the north-central States. In these contexts, mercenary fighters recruited from the rank and file of Sahelian herdsmen militia have often been involved in localized communal conflict, fighting for their pay-masters. Sometimes, the militant herdsmen would simply volunteer to come to the aid of a preferred conflicting party on the basis of ethno-religious affinity. A semblance of this played out in the Eggon (Ombatse)-Fulani crisis in Nasarawa State (2014-2015).

The involvement of migrant herdsmen in criminality and violence in northern Nigeria has complicated the security situation in the area, resulting in volatile inter-group relations, arms proliferations, human casualties and injury, force displacement of population, livelihood crises, and allied humanitarian disasters. It has accentuated the material suffering of the vulnerable rural population which has been sentenced to the margins of human security as a consequence.

The most strategic import of the foregoing is that Nigeria's national security is under a dire threat. The ease and impunity with which the marauding herdsmen infiltrate and terrorize Nigerian communities in the hinterlands adumbrate an acute failure of national security in a fast failing state of Nigeria.

\section{Conclusion and Recommendations}

Nomadic migrancy is one of the most dominant patterns of contemporary group migration in Africa. It has been driven by a combination of socio-ecological and economic factors that bear on the survival, subsistence, and sustainability of the nomadic tribe. In sub-Saharan Africa, nomadic migrancy is traditionally associated with the Fulani who constitute the bulk of the nomadic population in that context. The Fulani are mostly found in West Africa where their nomadic extraction engage in translocal and transnational transhumance. 
Nigeria constitutes a critical hotbed within the West African transhumance corridor. As such, it occupies a crucial place in the political economy of nomadic migration in the region, serving variously as a veritable point of origin, transits, and destination of nomadic migrancy. Nigeria witnesses influx of nomadic herdsmen from Mali, Niger and Chad on yearly basis. These migrants enter through the multifarious irregular routes that dot the northern axes of Nigeria's porous borderlines. Over the years, this pattern of migration has been associated with untoward tendencies that threaten national security in Nigeria.

This study explored the nexus between nomadic migrancy and rural violence in Northern Nigeria. It argued that unregulated migration has aggravated the incidence of rural violence in Northern Nigeria. It identified rural banditry, herdsmen militancy and arms proliferations as the complications of the nomadic migrancy menace, noting that the trend holds grave implications for national security in Nigeria. To arrest and reverse this trend, there is a need for the Nigerian government to institute a securitized border governance system capable of de-criminalizing nomadic migration and pastoralism.

In this regard, a transhumance regulation regime whereby the entry and movement of migrant herdsmen are documented and monitored should be instituted. This should be backed up by a digitally mastered system of range-surveillance by which the activities of the herdsmen are tracked in real time in the hinterlands in order to forestall their criminal and subversive tendencies. Lastly, there is a need for Nigerian government to institute a specialized rangeland guard system of community policing in an effort to fill the lacuna of conventional policing in Nigeria's vast and vulnerable countryside.

\section{References}

1. Adriansen, H. K. (2005). Pastoral mobility: A review. Nomadic Peoples NS, 9(182), 207214.

2. Ali, F. A. (2017, November 02). Winning Hearts and Minds in Ungoverned Spaces. United Nations Development Programme, Africa. Retrieved from http://www.africa.undp. org/content/rba/en/home/blog/2017/Winning-hearts-and-minds-in-ungovernedspaces.html.

3. Andrew, M. (1975). Why Big Nations Lose Small Wars: The Politics of Asymmetric Conflicts. World Politics, 27(2), 175-200.

4. Awogbade, M. O., Olaniyan, R. A., \& Faleye, O. A. (2016). Eco-Violence or Trans-Border Terrorism? Revisiting Nigerian Pastoral Nomadic Fulani's Question. In R. A. Olaniyan and R. T. Akinyele (Eds.), Nigerian's Ungoverned Spaces (pp. 41-58). Ile- Ife: Obafemi Awolowo University Press.

5. Bonga, F. E. (2017). Managing the Menace of the Fulani Herdsmen through Peace Education for National Integration. Multidisciplinary Journal of Research Development, 16(2), 1-6. 
6. Ceccato, V., \& Ceccato, H. (2017). Violence in the Rural Global South: Trends, Patterns and Tales from Brazilian Countryside. Criminal Review, 42(3), 270-290.

7. Clunan, A., \& Trinkunas, H. A. (2010). Ungoverned Spaces: Alternatives to State Authority in an Era of Softened Sovereignty. Palo Alto: Stanford University Press.

8. Coleman, P. T. (2000). Intractable Conflict. In M. Deutsch \& P. T. Coleman (Eds.), The Handbook of Conflict Resolution: Theory and Practice (pp. 428-450). San Francisco: Jossey Bass.

9. Diggins, C. A. (2011). Ungoverned Spaces, Fragile States and Global Threats: Deconstructing Linkages. Inquiries Journal, 3(3), 1-12.

10. Egwu, S. (2016). The Political Economy of Rural Banditry in Contemporary Nigeria. In M. J. Kuna and J. Ibrahim (Eds.), Rural Banditry and Conflicts in Northern Nigeria (pp. 13-68). Abuja: Centre for Democracy and Development (CDD).

11. Ensminger, J. \& Rutten, A. (1991). The Political Economy of Changing Property Rights: Dismantling a Pastoral Commons. American Ethnologist 18(4), 683-699.

12. Fall, B. B. (2015, September-October). The Theory and Practice of Insurgency and Counterinsurgency. Military Review, 40-48.

13. Federal Research Division-Library of Congress. (2008). Country Profile: Nigeria. Washington, D.C.: Federal Research Division, Library of Congress.

14. Feldman, R. L. (2009). The Causes of Terrorism: Why Parts of Africa Might Never be at Peace. Defense and Security Analysis, 25(4), 355-372.

15. Fisher, D., \& Mercado, C. (2014). Competitive Control: How to Evaluate the Threats Posed by Ungoverned Spaces? Small Wars Journal. Retrieved from http://smallwarsjournal. com/jrnl/art/“competitive-control”-how-to-evaluate-the-threats-posed-by-"ungover ned-spaces.

16. Forest, J. (2010). Engaging Non-State Actors in Zones of Competing Governance. Journal of Threat Convergence, 1(1), 10-22.

17. Goodall, S. K. (2007, May). From Plateau Pastures to Urban Fringe: Sedentarisation of Nomadic Pastoralists in Ladakh, North-West India. Ph.D Thesis. Department of Geographical and Environmental Studies, University of Adelaide.

18. Gray, B., Coleman, P. T., \& Putnam, L. L. (2007). Introduction, Intractable Conflict: New Perspectives on the Causes and Conditions for Change. American Behavioral Scientist 50(11), 1415-1429. doi: 10.1177/0002764207302459.

19. Homer-Dixon, T. F. (1994). Environmental Scarcities and Violent Conflict: Evidence from Cases. International Security, 19(1), 5-40.

20. Homer-Dixton, T. F. (1999). Environment, Scarcity and Violence. Princeton: University Press.

21. Inglehart, R., \& Welzel, C. (2005). Modernization, Cultural Change, and Democracy: The Human Development Sequence. Cambridge: Cambridge University Press.

22. IOM (2011). Glossary on migration ( $2^{\text {nd }}$ edition), No. 25. International Migration Law. Generva. International Organization for Migration. 
23. Janzen, J. (2005). Mobile Livestock-Keeping in Mongolia: Present Problems, Spatial Organization, Interactions between Mobile and Sedentary Population Groups and Perspectives on Pastoral Development. Senri Ethnological Studies, 69, 69-97.

24. Julum, J., \& Evans, D. (2015). The Spectre of Ungoverned Spaces \& How Advances in Network Analysis Can Assist Policymakers. Small Wars Journal. Retrieved from http:// smallwarsjournal.com/jrnl/art/the-specter-of-ungoverned-spaces-how-advancesin-network-analysis-can-assist-policymakers.

25. Kay, C. (2001). Reflections on Rural Violence in Latin America. Third World Quarterly, 22(5), 741-775.

26. Keister, J. (2014). The Illusion of Chaos: Why Ungoverned Spaces Aren't Ungoverned, and Why That Matters. Executive Summary, No. 766. Policy Analysis. Washington: CATO Institute.

27. Khazanov, A. M. (1994). Nomads and the outside world [2 ${ }^{\text {nd }}$ ed.]. Cambridge: Cambridge University Press.

28. Krung, E. G, DahIberg, L. L., Mercy, J. A., Zwi, A. B., \& Locano, R. (2002). World Report on Violence and Health. Geneva: World Health Organization (WHO).

29. Kurekova, L. (2011). Theories of Migration: Conceptual Review and Empirical Testing in the Context of the EU East-West Flows. Paper prepared for interdisciplinary conference on Migration, Economic Change, Social Challenge, April 6-9, University College, London.

30. Lamb, R. D. (2008, January). Ungoverned Areas and Threats from Safe Havens - Final Report of the Ungoverned Areas Project. Paper prepared for the Office of the Under Secretary of Defense for Policy by the Office of the Deputy Assistant Secretary of Defence for Policy Planning. Washington DC, United States. Retrieved from http://www. dtic.mil/dtic/tr/fulltext/u2/a479805.pdf .

31. Lee, E. [Ed.] (2009). Migration and Transnationalism: Pacific Perspectives. Acton: Australian National University and Library.

32. Lenshie, N. E. (2018). Political Economy of Ungoverned Spaces and Crude Oil Security Challenges in Nigeria's Niger Delta. Central European Journal of International and Security Studies, 12(1), 32-58.

33. Mallet, R. (2010). Beyond Failed States and Ungoverned spaces: Hybrid Political Orders in the Post-Conflict. eSharp, 15, 65-91.

34. Marsden, M. (2017, June 12). 'Ungoverned Spaces'?. Hurst Publishers. https://www. hurstpublishers.com/ungoverned-spaces/.

35. Martin, P. (2003). Bordering on Control: Combating Irregular Migration in North America and Europe. Migration Research Series, no. 13. Geneva: International Organization for Migration.

36. Marx, K. \& Engels, F. (1968). Selected Works. New York: International Publishers.

37. McDowell, C., \& Haan, A. (1997). Migration and Sustainable Livelihoods: A Critical Review of the Literature. IDs Working Paper, No.65. Brighton: Institute of Development Studies. 
38. McGregor, A. (2014). Connection between Boko Haram and Nigeria's Fulani Herdsmen could Spark a Nigerian Civil War. Terrorism Monitor, 12(10), 8-10.

39. Menkhaus, K. (2007, January 25-27). Terrorist Activities in Ungoverned Spaces: Evidence and Observations from the Horn of Africa. Paper prepared for the Southern Africa and International Terrorism Workshop, Tswalu, South Africa.

40. Menkhaus, K. (2010). Chapter Nine: State Failure and Ungoverned Spaces. Adelphi Series 50(412-413), 171-888.

41. Mulianga, B. A. (2009). Modeling Pastoral Mobility to Accommodate Pastoral Land Use in Land Administration: A Case Study of the Isiolo Area, Kenya. M.Sc. Thesis, University of Southampton, United Kingdom.

42. Newman, S. (1991). Does Modernization Breed Ethnic Political Conflict? World Politics, 43(3), 451-478. doi:10.2307/2010402.

43. Nigeria World Today (2017, April 19). How Fulani herdsmen are smuggling arms into Nigeria. Nigeria World Today. Retrieved from http://www.nigeriaworldtoday.com/arti cle-on-nigeria/how-fulani-herdsmen-are-smuggling-arms-into-nigeria/.

44. Northrup, T. A. (1989). The Dynamic of Identity in Personal and Social Conflict. Syracuse, NY: Syracuse University Press.

45. Odoh, S. I., \& Chigozie, C. F. (2012). Climate Change and Conflict in Nigeria: A Theoretical and Empirical Examination of the Worsening Incidence of Conflict between Fulani Herdsmen and Farmers in Northern Nigeria. Arabian Journal of Business and Management Review (Oman Chapter), 2(1), 110-124.

46. Okoli, A. C. (2016). Pastoral Transhumance and Dynamics of Social in Nasarawa State, North-Central Nigeria. In M. J. Kuna and J. Ibrahim (Eds.), Rural Banditry and Conflicts in Northern Nigeria (pp. 389-447). Abuja: Centre for Democracy and Development (CDD).

47. Okoli, A. C. (2017). Cows, Cash and Terror: How cattle rustling proceeds fuel Boko Haram insurgency in Nigeria. CODESRIA Policy Dialogue Conference on 'Money, Security and Democratic Governance in Africa', held in Bamako, Mali, $19^{\text {th }}-20^{\text {th }}$, October, 2017.

48. Okoli, A. C. and Atelhe, G. A. (2014). Nomads against Natives: A Political Ecology of Herder/Farmer Conflicts in Nasarawa State, Nigeria. American Journal of Contemporary Research, 4(2), 76-88.

49. Okoli, A. C., \& Ochim, F. I. (2016). Forestlands and National Security in Nigeria: A Threat-Import Analysis. IIARD International Journal of Political and Administrative Studies, 2(2), 68-74.

50. Okoli, A. C., \& Okpaleke, F. N. (2014). Banditry and Crisis of Public Safety in Nigeria: Issues in National Security Strategic. European Scientific Journal, 10(4), 350-362.

51. Olaniyan R. A., \& Akinyele, R. T. (2017, March 15). Studying Nigeria's Ungoverned Spaces. The Nation. Retrieved from http://thenationonlineng.net/studying-nigerias-ungover ned-spaces/.

52. Olayoku, P. A. (2014). Trends and Patterns of Cattle Grazing and Rural Violence in Nigeria (2006-2014). IFRA- Nigeria e-papers no 34. Ibadan: French Institute for Research in Africa. 
53. Omitola, B. (2014, August). Between Boko Haram and Fulani Herdsmen: Organized Crime and Insecurity in Nigeria. Paper presented at the $5^{\text {th }}$ Institute of Security Studies conference on Crime and Crime Reduction, 14 and $15^{\text {th }}$ August, Sandton, South Africa.

54. Putnam, L. L., \& Wondolleck, J. (2003). Intractability: Definitions, Dimensions, and Distinctions. In R. J. Lewicki, B. Gray, \& M. Elliott (Eds.), Making Sense of Intractable Environmental Conflict: Concepts and Cases (pp. 35-59). Washington, DC: Island Press

55. Rabasa, A., Boraz, S., Chalk, P., Cragin, K., Karasik, T.W., Moroney, J.D.P., O’Brien, K.A., \& Peters, J. E. (2007). Ungoverned Territories: Understanding and Reducing Terrorism Risks. Santa Monica, CA: RAND Project Air Force.

56. Raleigh, C., \& Dowd, C. (2013). Governance and Conflict in the Sahel's 'Ungoverned Spaces'. Stability: International Journal of Security \& Development, 2(2), 1-17. DOI: http://dx.doi.org/10.5334/sta.bs

57. Rufai, M. A. (2016). The Role of Vigilante Groups in the Fight against Rural Banditry in Zamfara State, North-Western Nigeria. Draft paper, Department of History, Usmanu Danfodiyo University, Sokoto (UDUS), Nigeria.

58. Scholz, F. (1995). Nomadism: Theory and Change of Socio-Ecological Mode of Culture. Stuttgart: Franc Steiner Verlag.

59. Smith, A. R. (2014). Intractable Conflict. Key Concepts in Intercultural Dialogue, No. 18. Centre for Intercultural Dialogue. Washington, DC, USA: Council of Communication Association.

60. Taylor, A. J. (2016). Thought on the Nature and Consequences of Ungoverned Spaces. SAIS Review of International Affairs 36(1), 5-15.

61. Uwujire, N. (2017, March). Fake Herdsmen: Road Ends for Fulani Kidnappers in Nigeria. The Sun. Retrieved from http://sunnewsonline.com/fake-herdsmen-road-ends-forfulani-kidnappers-in-niger/.

62. Whelan, T. (2005, December 19). Africa's Ungoverned Spaces - A New Threat Paradigm. Paper delivered at the Rethinking the Future Nature of Competitions and Conflict Seminar Series, Laurel, Maryland, United States: The Johns Hopkins Applied Physics Lab. Whelan, T. (2006). Africa's Ungoverned Spaces. Briefing addressed at the Portuguese National Defence Institute, Lisbon. 